\title{
Eyelid Carcinoma pT1a TNM Finding v8
}

National Cancer Institute

\section{Source}

National Cancer Institute. Eyelid Carcinoma pT 1a TNM Finding v8. NCI Thesaurus. Code C140490.

Eyelid carcinoma with tumor measuring $10 \mathrm{~mm}$ or less in greatest dimension without invasion of the tarsal plate or eyelid margin. (from AJCC 8th Ed.) 